\title{
"A fo Ben bid bont": New Directions for Plaid Cymru? The Ceredigion Result in the UK General Election of 2017
}

'A fo Ben bid bont' : Plaid est-il en partance pour de nouvelles destinations?

L'élection législative britannique de juin 2017 dans le Ceredigion

\section{Carys Lewis}

\section{OpenEdition}

\section{Journals}

Electronic version

URL: http://journals.openedition.org/rfcb/2219

DOI: $10.4000 /$ rfcb.2219

ISSN: 2429-4373

Publisher

CRECIB - Centre de recherche et d'études en civilisation britannique

\section{Electronic reference}

Carys Lewis, «"A fo Ben bid bont": New Directions for Plaid Cymru? The Ceredigion Result in the UK General Election of 2017 », Revue Française de Civilisation Britannique [Online], XXIII-2 | 2018, Online since 14 September 2018, connection on 02 May 2019. URL : http://journals.openedition.org/ rfcb/2219; DOl : 10.4000/rfcb.2219

This text was automatically generated on 2 May 2019.

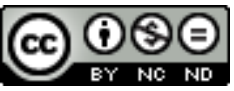

Revue française de civilisation britannique est mis à disposition selon les termes de la licence Creative Commons Attribution - Pas d'Utilisation Commerciale - Pas de Modification 4.0 International. 


\title{
"A fo Ben bid bont": New Directions for Plaid Cymru? The Ceredigion Result in the UK General Election of 2017
}

\author{
'A fo Ben bid bont' : Plaid est-il en partance pour de nouvelles destinations? \\ L'élection législative britannique de juin 2017 dans le Ceredigion
}

Carys Lewis

\section{Introduction}

1 Had it not been for the soothing attributes of the Welsh landscape, the UK 2017 General Election might never have seen the light of day. This at least was the suggestion made by Prime Minister Theresa May herself when announcing on Tuesday April 18 that she had decided to call a snap election on June $8^{\text {th }}$. Her five-day holiday in early April in the area around the town of Dolgellau in Gwynedd had provided her with the ideal space in which to gather her thoughts since "walking in Wales is an opportunity to get out and about and see scenery and clear your mind and your thinking".

2 A little further south to the area where Theresa May came to her momentous decision lies the equally rural county of Ceredigion where a battle was to be fought during the 2017 General Election in which the victorious party, Plaid Cymru, would have to demonstrate the same clear-headedness and self-assured thinking displayed by PM May in her decision to go for an early election. The present paper will therefore seek to show how the result in the Ceredigion constituency might herald a new dawn in the way Plaid Cymru seeks to position itself in the post-Brexit Wales, especially in terms of the youth vote and on the question of a potential push for Welsh independence. 


\section{Ceredigion: a brief overview}

3 The county known since 1282 in English as the county of Cardiganshire takes its present name from an old Welsh kingdom of the Middle Ages that comprised territory roughly equivalent to today's Ceredigion. The population was given as 79,500 in the 2011 census, $47.3 \%$ of whom were Welsh-speakers, the third-highest percentage for a Welsh county. ${ }^{2}$ The Ceredigion economy is heavily dependent on farming and tourism, although farming revenues have been in steep decline in recent years. The county prides itself on its pristine landscapes and wild mountain hinterland to attract a tourist clientele of families and aficionados of outdoor activities, many of whom choose to stay and make the county their home. ${ }^{3}$

4 It has few towns of any size. Aberystwyth is the largest, with a population of 13,040 according to the 2011 census or 18,965 if the outlying suburbs of Llanbadarn, Waunfawr and Commins Coch are included, in which a large proportion of the town's student population is housed. ${ }^{4}$ With its university set up in 1872 , it is considered the cultural capital of Wales: the town houses the National Library of Wales, the National Screen and Sound Archives of Wales, the headquarters of the Welsh Books Council, the Royal Commission on the Ancient and Historical Monuments of Wales, and those of Cymdeithas yr Iaith Gymraeg (the Welsh Language Society) and UCAC (Undeb Cenedlaethol Athrawon Cymru, the National Union of Teachers in Wales). The National Assembly for Wales has opened decentralised offices there. All in all it is a town that punches well above its weight.

5 Elsewhere in Ceredigion a second university may be found in the south of the county, in the town of Lampeter. The administrative capital is located in the coastal town of Aberaeron, commodiously situated in a central position. It is this combination of highlyskilled, intellectual, politically-active and pro-European groups within the population of Ceredigion that melds together to create a quite astonishingly vibrant society throughout the county, as is attested by the results of the EU Referendum of June $2016^{5}$ as well as other less conventional measurements of political activism. ${ }^{6}$

However, such an idyllic vision of a highly-educated and politically-aware Arcadia should not lull the reader into complacency: Ceredigion can reel off a litany of equally astounding statistics when it comes to levels of social and economic deprivation. In 2008, around $66 \%$ of the adult working population were in employment, compared with $71 \%$ in Wales. ${ }^{7}$ Average (mean) gross weekly earnings in Ceredigion for 2015 were $£ 490$ compared to $£ 550$ for Wales in the same year. ${ }^{8}$ Of all the UK regions surveyed in April 2017, Wales came last in terms of median full-time gross weekly earnings, even though there was a $1 \%$ increase on the result from the previous year. ${ }^{9}$ Child poverty rates in Ceredigion are among the highest in Wales: recent figures estimate that 3,500 children in the county are estimated to be living in poverty, the seventh-highest figure in Wales. ${ }^{10}$ West Wales has regularly been the recipient of EU Structural Funds and the area is noted as being one of the areas with the lowest GDP in the EU as illustrated in the map below. ${ }^{11}$ 


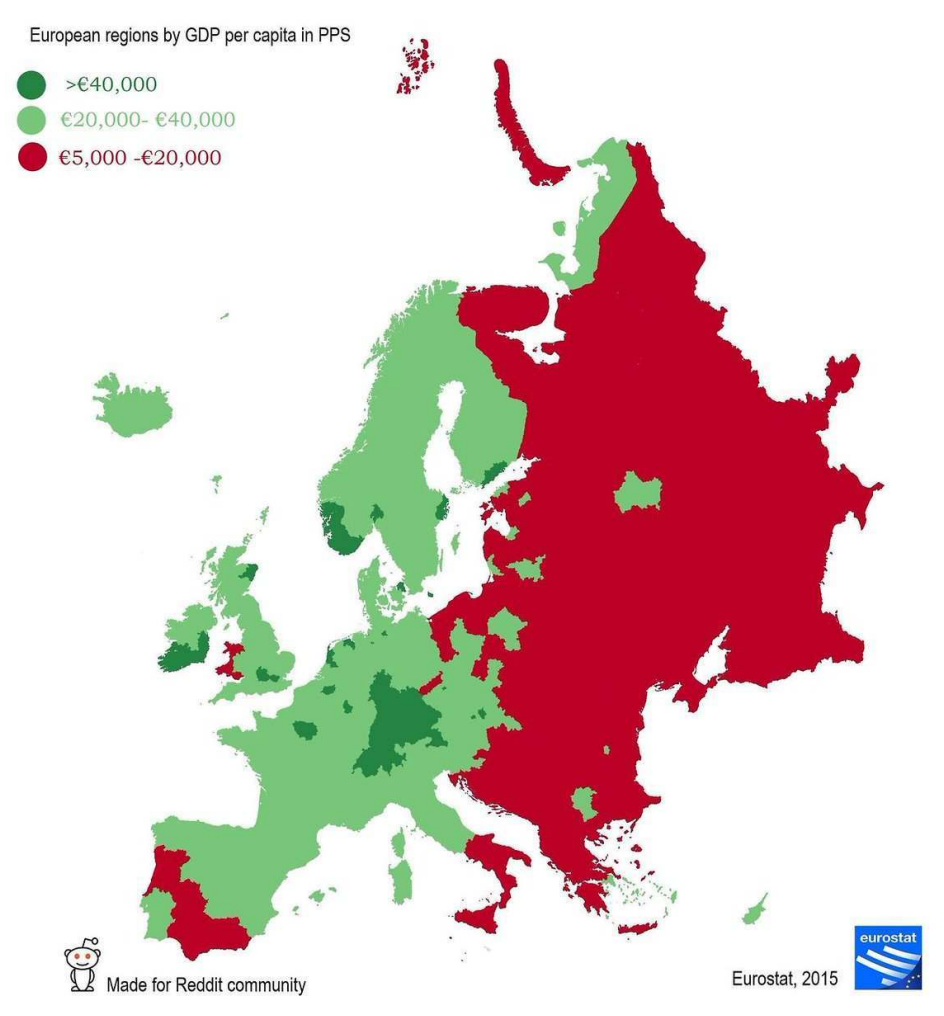

\section{Ceredigion's political history}

7 If one goes back to the setting up of a modern administrative Wales, the Act of Union of 1536 conferred one MP on the county of Cardiganshire and one for the five boroughs contained within its boundaries, ${ }^{12}$ and these constituencies were duly carved up between local aristocratic families, mostly in totally uncontested elections up until the end of the eighteenth century. Around this time, the boom-and-bust existence of the Pryses of Gogerddan, the Powells of Nanteos and the Vaughans of Trawscoed began to experience the political stirrings of the non-conformist denominations, whether it be the Unitarians in the south of the county, who went on to petition parliament for Chartism in 1839, or the Calvinistic Methodists in 1835, who contested the right of the Church of England to levy a rate to rebuild St. Michael's church in Aberystwyth and in a short-lived publication in the Welsh language, drew traitorous parallels with the Irish question of non-payment of tithes. These "rustlings of radicalism"13 are maybe best epitomized in the episode known in Welsh as Rhyfel y Sais Bach or the War of the Little Englishman. This was the name given to the land riots of 1819-20 when common land on Mynydd Bach, Trefenter was sold to one Augustus Brackenbury who went on to build a house there. The house was attacked, looted and burnt three times by local people, eventually leading Brackenbury to decamp, selling off the land in parcels. ${ }^{14}$

The mid-nineteenth century saw a series of elections besmirched by vote-rigging and tenant evictions, all of which culminated in 1869 with a Commons select committee inquiry into alleged election malpractice in Cardiganshire. The allegations were laid against Tory landlords, who had the nasty habit of evicting Liberal-voting farm tenants. When Gladstone's Liberal government of 1872 brought in the secret ballot, this largely 
put an end to such behaviour. Not long after, in 1874, Thomas Edward Lloyd of Coedmor was the last Tory landowner to represent the county.

The Liberals who represented the county from then on were, however, no radicals - they could be described more as Whigs. In 1885, when the last of the borough seats was abolished, leaving only the county seat, industrialist and coal magnate David Davies Llandinam stood as "the Working Man's Friend" 15 and was elected. Yet, with Davies it seemed as if the bad old days of corrupt electioneering were back again; he spent his time and wealth buying up land and votes. The last straw came when Davis voted against Irish home rule. He was promptly deselected in 1886. In the words of historian Gerald Morgan "the genuine radicalism of south Cardiganshire Unitarians and the growing Aberystwyth intelligentsia never found expression in parliamentary terms" ${ }^{16}$ Apart from a little in-fighting amongst Cardiganshire Liberals in the 1920s, reflecting the more general animosity between pro-Asquith and pro-Lloyd George forces in the party, the parliamentary elections were a two-horse race between Liberal and Tory candidates, with Labour managing to elbow its way into second place in the election of 1931.

In the modern era, the first jarring interruption in the cosy succession of Liberal MPs to represent the constituency came in 1966, that year of other breakthroughs in Wales with the election of Gwynfor Evans, the first ever Plaid MP, elected in the Carmarthenshire byelection. In the 1966 Cardiganshire constituency a young and ambitious Welsh-speaking solicitor named Elystan Morgan became the Labour candidate and unseated the Liberal incumbent Roderick Bowen, who had represented the county since the post-war election of 1945. Morgan was in fact a defector from Plaid Cymru; in the 1964 general election he had unsuccessfully fought as a Plaid candidate in the neighbouring constituency of Meirionydd. A native of Bow Street, in the north of the county, Morgan was a local boy made good. He went on to hold the seat for Labour in the 1970 election when Heath was elected.

11 The Liberals soon fought back in the February election of 1974, with the election of a candidate embodying most completely the make-up of the constituency's electorate. Geraint Howells was a Welsh-speaking local farmer, embedded in the cultural and social life of the county. Howells and Elystan Morgan were culturally cut from the same cloth; both were from north Cardiganshire farming families, both were prominent members of their non-conformist chapels, so there was very little to distinguish them apart from more societal questions in which the Labour Party in Wales held diametrically opposing views to those of Plaid Cymru. A question of this order reared its head in the matter of the setting up of a Welsh-medium comprehensive school to cover the catchment area of Aberystwyth. Howells was a firm supporter of Ysgol Gyfun Penweddig, the bilingual comprehensive set up in 1973. The battle for the opening of such a school had left its mark on the Welsh-speaking population of north Cardiganshire, which could in effect explain the more than $10 \%$ swing in the vote from Labour to the Liberals. Howells went on to hold the seat in 1979, 1983 and 1987.

12 Another shake-up came in 1992. Suffering from a bad knee that made it difficult for him to cover the hustings in what was now a huge constituency - Cardiganshire had become Ceredigion and Pembroke North in the redrawing of boundaries in 1983 - Geraint Howells lost his seat by 3,000 votes to Cynog Dafis, his Plaid opponent who had come fourth in the previous election. Dafis and Plaid had entered into a strategic alliance with the Green Party, yet this cannot fully explain the Plaid victory since the Greens only polled just over 800 votes in the 1987 election. It could possibly be put down to the seeds of the 1970 s 
environmentalist movements that were so prevalent in the mid Wales of the times and which were beginning to bear fruit some twenty years later. The politically explosive and divisive question of the Welsh language was also perhaps being looked at in a new light. It was more than twelve years since the Tories had come to power in Westminster and Margaret Thatcher had wreaked havoc in Welsh communities the length and breadth of the country. Voters were slowly coming to the conclusion that there had to be a change in the way things had always been done.

Cynog Dafis held onto his seat in 1997, with a majority of 7,000 over Labour. In 1999 Dafis also became an Assembly Member in the newly-established National Assembly for Wales through the regional list vote, but he soon found that both jobs were too demanding. He resigned his Westminster seat in 2000, triggering a by-election that was successfully won by Plaid's Simon Thomas, who went on to hold the seat in the 2001 election.

In 2005 Thomas was beaten by a certain Mark Williams, who had once been a parliamentary researcher for Geraint Howells. Williams had slowly been building the Liberal - by now the LibDems - vote back to its top rank through the by-election of 2000 and the general election of 2001, finally overturning the Plaid hegemony with a 9.7\% swing in 2005. He went on to hold on to the Ceredigion constituency comfortably in 2010, increasing his vote by $13.5 \%$, but the warning signs of what was to happen in 2017 could maybe have been detected in 2015, when Mark Williams's increased vote turned into a $14.2 \%$ drop in what was an acrimonious election campaign. ${ }^{17}$

\section{The 2017 General Election in Ceredigion}

When the monks of the fourteenth or fifteenth centuries were busy inscribing The Mabinogion ${ }^{18}$ onto the earliest manuscript in which the stories can be found, little did they think that centuries later, one of the now famous sentences from the second branch would become a campaign slogan in the Ceredigion General Election of 2017. A fo Ben bid bont - to be a leader, you must be a bridge - the catch-phrase chosen for Ben Lake's winning Plaid Cymru campaign with a capital B for Ben, was characteristic of the welloiled and solid campaign Lake conducted in Ceredigion.

If Plaid had been looking to select a candidate that would in some way prove to be a greater attraction to younger voters than whatever candidate the Labour Party would field, then the choice of Ben Morgan Lake turned out to be a stroke of genius. Plaid was forced to recognize that after the disappointment of the EU Referendum result that Welsh youngsters undoubtedly felt, many would be tempted by the tantalizing appeal that a Jeremy Corbyn-led Labour Party seemed to offer. The Party of Wales would therefore have to pull out all the stops to find a candidate that could appeal to the core youth vote in Ceredigion - students in Aberystwyth or Lampeter universities could elect to cast their vote in the constituency if they chose - whilst drawing sufficient numbers of traditional rural Welsh Plaid voters. It was always going to be a race to beat Labour; after all, Plaid had already targeted the seat in the 2015 election as winnable and, had it not been for the debacle around Mike Parker, they would have gained it back from Mark Williams, whose majority had been greatly reduced. Yet, when Ben Lake was selected, nobody could have predicted the final surge in Corbyn's campaign, not least among young voters.

Ben Morgan Lake was born in 1993 and brought up in a Welsh-speaking family. He attended Lampeter Comprehensive School and went on to graduate from Trinity College 
Oxford with a degree in History and Politics, later completing a Master's in Modern British and European History. He worked as a research officer for Elin Jones, Ceredigion AM and current Presiding Officer, at the Welsh Assembly. He has stated that he sees himself in the legacy of his predecessors:

I am a new name in Ceredigion politics but I hope to belong to a long tradition of Ceredigion MPs who made their mark on Westminster politics - from Elystan Morgan to the late Geraint Howells, and of course Cynog Dafis. More than ever, Westminster needs to hear Ceredigion's voice. ${ }^{19}$

Yet again, the campaign was acrimonious. Accusations of skulduggery and slandering from the LibDems were bandied about by Plaid, and were possibly even embarrassing to the LibDem incumbent himself, Mark Williams, who had found himself lumbered with a young and inexperienced campaign manager that the LibDem central office had sent up to Ceredigion and who possibly underestimated the damage done to Williams' credibility through attacking Plaid on its so-called acceptance of Brexit. However, media pundits right up to the very day of the election had not suspected a Plaid victory.

Late into the early hours of the morning of June $9^{\text {th }}$ and after two recounts, Ben Lake was declared the winner, a mere 104-vote difference between him and Williams. It was a historical result: for the first time since 1859, no constituency in Wales would be sending a Liberal MP to Parliament. The results were as shown below:

\begin{tabular}{|l|l|l|l|}
\hline Candidate & Party & $\begin{array}{l}\text { Number } \\
\text { votes }\end{array}$ & $\begin{array}{l}\text { of } \\
\text { votes }\end{array}$ \\
\hline $\begin{array}{l}\text { DAVIES, of } \\
\text { Rosamund }\end{array}$ & Conservative & 7,307 & $18.37 \%$ \\
\hline HAM, Grenville Morgan & Greens & 542 & $1.36 \%$ \\
\hline HARRISON, Tom & UKIP & 602 & $1.51 \%$ \\
\hline LAKE, Ben Morgan & Plaid Cymru & 11,623 & $29.23 \%$ \\
\hline MULHOLLAND Dinah & Labour & 8,017 & $20.16 \%$ \\
\hline SIR DUDLEY, the Crazed & $\begin{array}{l}\text { Official Monster Raving Loony } \\
\text { Party }\end{array}$ & 157 & $0.39 \%$ \\
\hline WILLIAMS, Mark & Liberal Democrats & 11,519 & $28.97 \%$ \\
\hline
\end{tabular}

\section{Did Brexit play a role in the Ceredigion General Election result?}

In West Wales, the EU funded the equivalent of $€ 1,078$ per head in 2014 , so for the most astute voters, the Remain vote should have been a given in the EU Referendum of 2016. The figure of $68 \%$ of Welsh exports going to the EU, especially in farming, was also known at the time, but this did not seem to prevent some rural areas of Wales, heavilydependent on agriculture, from voting to leave the EU. Ceredigion seemed to buck the trend that other parts of rural, agricultural Wales demonstrated in the Brexit vote. The EU Referendum also dredged up a lot of disquieting discourses on national identity: so what about the question of national identity, or should one say identities? There is 
some evidence to show that the way people self-identify in the UK could indicate how they voted in the EU Referendum. A sample study of voters has shown the breakdown of support for Leave versus Remain by primary national identity. In the study Leave supporters were defined as those who either voted Leave in the referendum or said they would have done so if they had voted. (Remain supporters were defined in the same way.) $47 \%$ of those who saw themselves primarily as British supported Leave in the referendum. A full $65 \%$ of those who saw themselves primarily as English supported Leave. $52 \%$ of those who saw themselves primarily as Welsh supported Leave, along with $35 \%$ of those who saw themselves primarily as Scottish, $42 \%$ of those who saw themselves primarily as Northern Irish and only $30 \%$ of those who saw themselves primarily as Irish. ${ }^{20}$

Yet, as recent figures of self-identification in Wales have shown, the question of the Welsh language does not correlate with what most experts would expect to be a strong form of self-identification as Welsh, so being a Welsh-speaker is not enough to explain the Brexit vote. ${ }^{21}$ However, the results in the map below would seem to suggest that Ceredigion has a greater self-identification with Britishness rather than Welshness. Conversely, the populations of the South Wales Valleys identify themselves as Welsh with percentages of $75 \%$ to over $80 \%$ in places and yet it was these same valleys that overwhelmingly rejected the $\mathrm{EU} .^{22}$

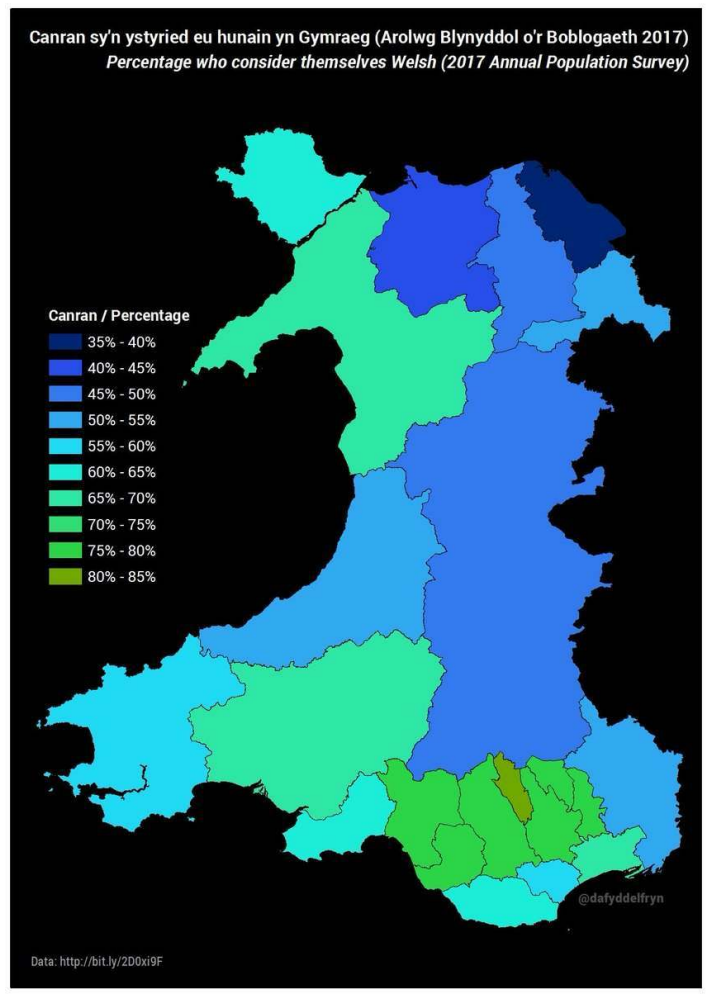

There is possibly a more pertinent divide along the East/West lines in Wales as the two maps below might suggest. ${ }^{23}$ The overlap of areas where the Welsh language is still very prevalent and Plaid Cymru-voting areas could once again be one way of explaining how the Ceredigion constituency was bagged by Plaid as one of its natural stomping grounds. 


\section{Correlation Brexit/GE Results}
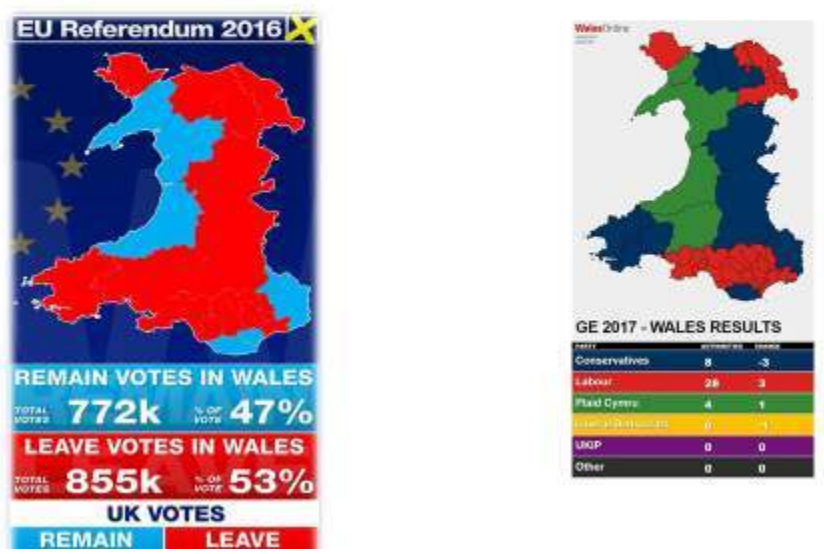

\section{The five factors that impacted the EU Referendum vote in Wales and their importance in the 2017 General Election in Ceredigion}

Welsh researchers since the EU Referendum of June 2016 have highlighted five factors that could have influenced the EU Referendum result which we shall discuss here in relation to their impact on the Ceredigion 2017 General Election result. The five factors listed as having in some way contributed to the Welsh EU Referendum result were (1) Labour hegemony (2) English in-migration (3) EU funding (4) the democratic deficit in Wales, resulting in an alienated, impoverished, angry population (5) the lack of Welsh media leading to an information deficit

In the 2017 General Election in Ceredigion, Labour performed well, mirroring Jeremy Corbyn's UK-wide result, especially among the youth vote. There was also a tactical vote that was discernible in the highly Remain-voting areas of Wales - and Ceredigion was a perfect example of this - consisting in choosing to vote Labour over one's choice of party in the 2015 General Election, if only in the hope of stopping Brexit. In terms of the Ceredigion result, there is no doubt that this tactic played heavily on both Ben Lake's and - to a lesser extent - on Mark Williams's traditional electors as the following table of vote flows might suggest:

Vote flows Remain voters, Wales General Elections 2015-17 (source: British Election Study, 2017) ${ }^{24}$ 


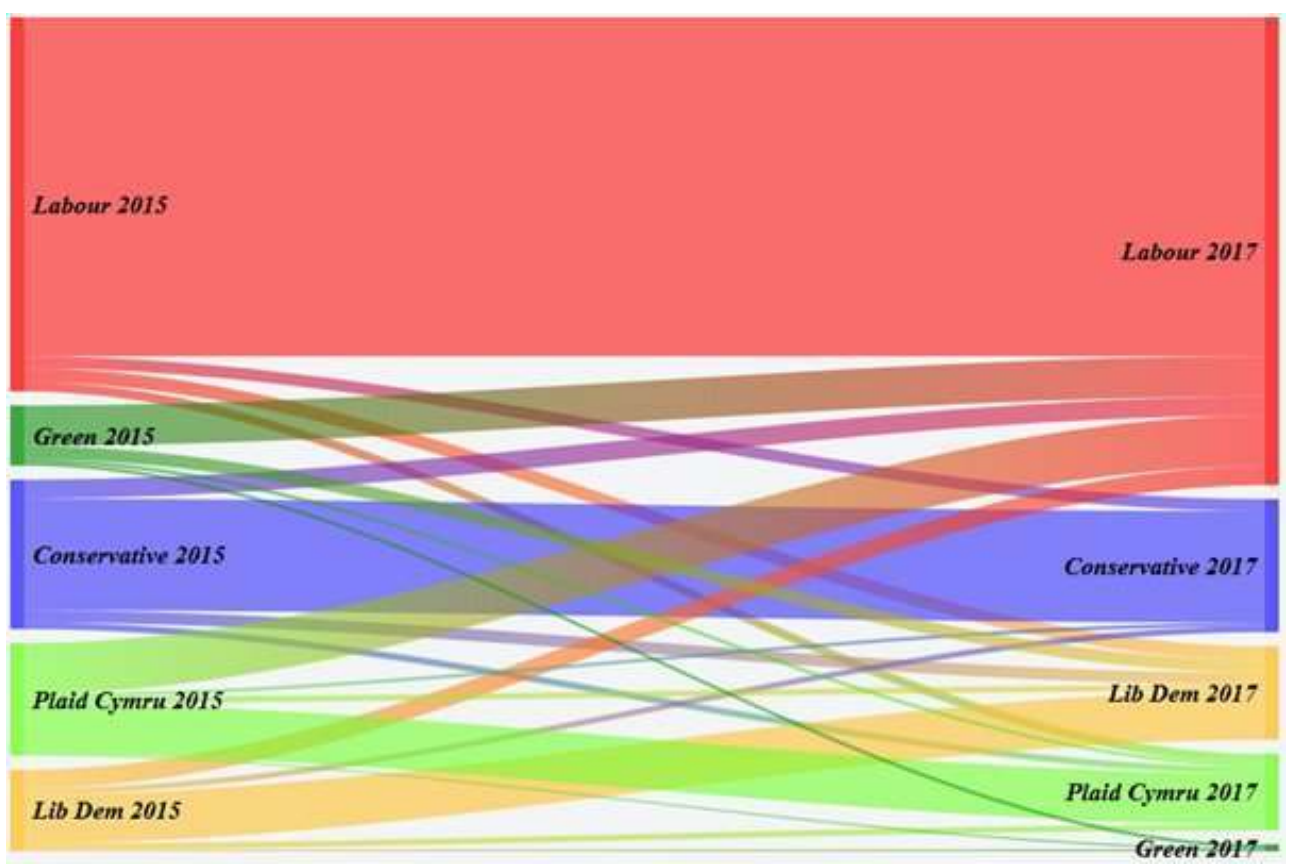

27 The Remain voter vote flows are particularly instructive regarding the Plaid Cymru vote since the more left-leaning Plaid under Leanne Wood has possibly legitimized the socialist/left-wing narrative for Plaid-voting Welsh-speakers to the extent that they can now contemplate voting Labour in constituencies such as Ceredigion when tactical voting is called for. Plaid also loses out when the overall vote flows by party are examined in Wales in the figure below:

Vote flows by party, Wales General Elections 2015-17 (source: BES Research)

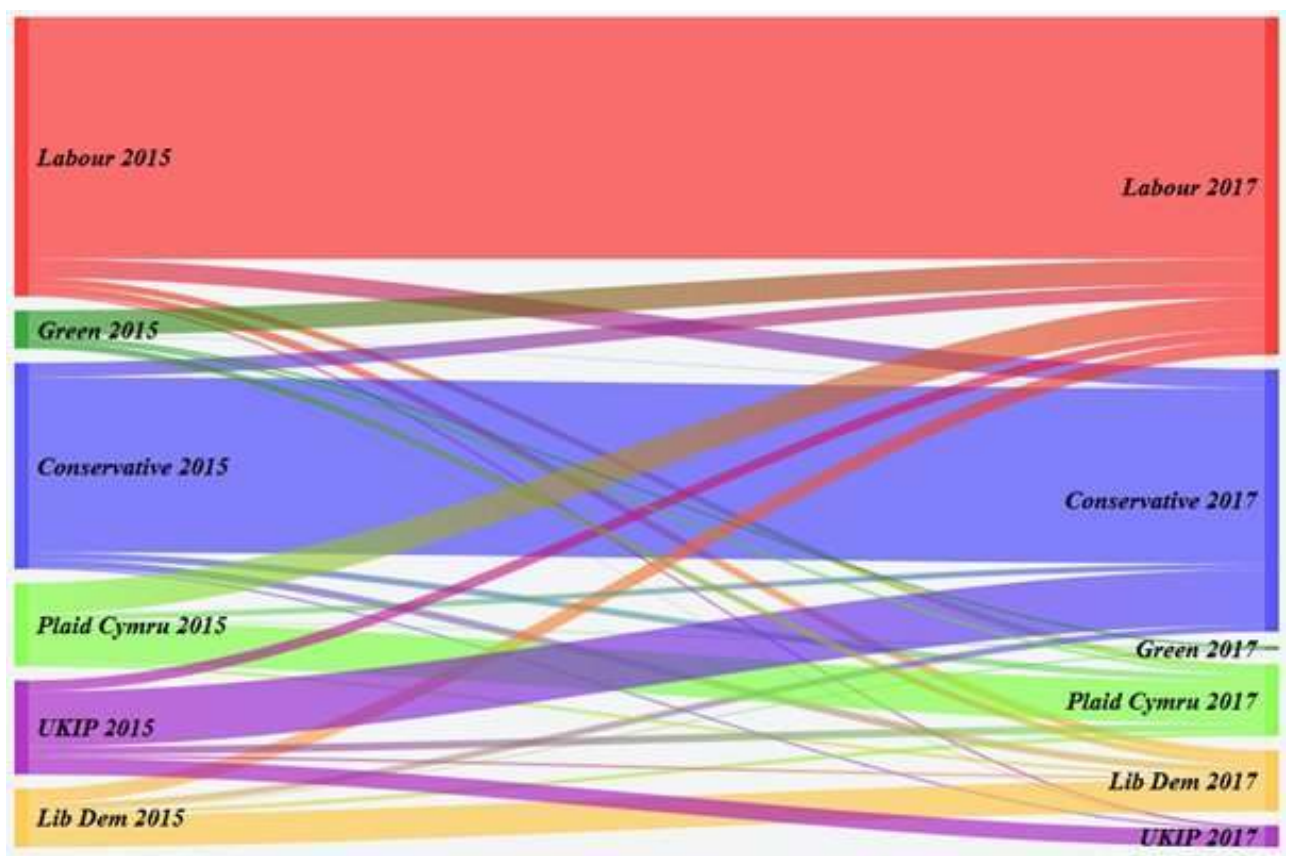

Only UKIP suffers a greater migration of its voters from 2015 to 2017. Both The Green Party and Plaid Cymru, who were once in an alliance in Ceredigion, found that many of their 2015 electors migrated over to Labour in the 2017 General Election. When commentators hail the resistance of Labour in Wales in the 2017 election, shifts in voting patterns as shown in the above figures should not be underestimated. For Plaid there are 
lessons to be learnt and a necessary future repositioning of the party in anticipation of the Labour Party persisting in its left-leaning agenda, even though this is not so much the case with the Labour Party in Wales.

On the question of English in-migration, in Ceredigion the phenomenon is probably more significant in relation to the Remain vote as the highly-skilled intellectual workers of the universities and various research centres in the county could possibly have contributed to Ben Lake's victory. English in-migration elsewhere in Wales, especially the migration of English retired people to the North Wales coastal areas such as Conwy and Clwyd West, probably fed into the EU Referendum Leave vote and acted as a bulwark for the Conservative votes there, despite significant increases in the votes for Labour candidates in those constituencies.

31 Ceredigion is acutely aware of the necessary funding to maintain public services in the county and nowhere was this more apparent than in the fight against Ceredigion county council austerity measures that led to the closure of Bodlondeb, an old people's home in Aberystwyth. ${ }^{25}$ As mentioned above, Ceredigion and West Wales in general make up some of the poorest and most deprived areas in the UK, therefore, even though the decision concerning the closure of the care home was wholly that of the county council, people understood that the austerity measure that the council was faced with were imposed on it by central government. Maintaining EU funding in these cases became even more essential, which is probably what many Remain voters in Ceredigion had understood in June 2016. This incident could also explain the high Labour vote in Ceredigion since the health workers union had been extremely active in trying to save the care home.

As far as the "alienated, impoverished, angry population" factor is concerned, this probably had more impact in other parts of Wales. It was certainly picked up by the press in the immediate aftermath of the EU Referendum result in Wales in such places as Ebbw Vale and other parts of the South Wales Valleys. ${ }^{26}$ Long-standing cultural and political activism in Ceredigion, especially amongst Welsh-speakers, has instilled a culture of fighting for one's rights and campaigning for recognition beyond mere UK institutions, hence the perception of the $\mathrm{EU}$ as a more benign seat of power than those closer to home. Yet, despite the fact that Ceredigion does not have its share of disenchanted postindustrial voters that fuelled the Leave vote elsewhere in Wales, UKIP has made inroads in the county in the National Assembly elections.

Finally, the matter of an information deficit due to a lack of uniquely Welsh media is perhaps less pronounced in Ceredigion, especially once again among Welsh-speakers, who are able to access a tradition of community newspapers - papurau bro - offering a different perception of daily life and news. Some of these papers include occasional forays into more national or even international topics worthy of discussion. However, Plaid Cymru in particular cannot rely on the pool of Welsh language activists/speakers to bolster its electorate in the future, especially if the party decides to put the question of Welsh independence on the agenda in the wake of a disastrous Brexit for Wales.

\section{The youth vote}

Whether or not there was a "youthquake" in the UK in the General Election of 2017 is very much still up for discussion, ${ }^{27}$ and there is no concrete evidence to support a strong youth turnout in Ceredigion, apart from the fact that the county is home to two 
universities and students can be registered to vote in their place of study. The youth question is one that could have a more long-term bearing on the constituency, a preoccupation that was voiced in Ben Lake's maiden speech to parliament. Referring to " the tragic irony that Ceredigion bestows upon its youth an unrivalled education, but offers them a paucity of job opportunities and affordable housing", with "around half her young people leaving the county by the time they reach 25 years of age", Ben Lake linked this exodus to the language question, pointing out that "many of the young who have left are Welsh speakers" and "the percentage of people living in Ceredigion that can speak the language has dropped from around $60 \%$ to $47 \%$. This steady, silent haemorrhage, saps the life of nearly every town and village the length and breadth of the county". ${ }^{28}$ Wales is one of three regions in the UK which has a deficit in the number of graduates that it trains and that leave to pursue their careers elsewhere, the other two being the Midlands and the North-East of England, both regions in which Brexit found strong support. ${ }^{29}$ If constituencies like Ceredigion are to have any hope of turning such figures around, all the political parties in Wales need to come together and offer better long-term prospects to its youth.

\section{A push for independence?}

So, what next for Wales? And what next for Plaid Cymru? Could Ben Lake epitomize the new breed of MPs that are going to be necessary if Wales is to be lifted from its position of poor woman of the UK and Europe?

There are rumblings of change afoot. Under the leadership of Leanne Wood and in the wake of the independence referendum in Scotland in 2014, Plaid Cymru activists are embracing the idea of working towards some form of Welsh independence. The Brexit result has also proven to be a wake-up call for the party. Shortly after the EU Referendum result was announced, a rally was held in Aberystwyth by a group called YesCymru. ${ }^{30}$ Modeled on the YesScotland movement during the Scottish independence referendum, YesCymru was officially set up in 2014 and is a grassroots campaign group with no party political affiliations, made up of regional groups and no central headquarters. It is proving to be an intense magnet for young activists in Wales, especially through its use of social networks. The group has published a small booklet called Independence in your pocket - based on the Wee Blue Book of the Scottish referendum movement. YesCymru could outflank Plaid among the young voters of Wales, especially among young South Walians.

Perhaps Plaid Cymru are aware of the need to focus on the youth of Wales since a Plaid Ifanc (Young Plaid) was set up in September 2017. In its constitution document, it sets out a clear mission statement:

Plaid Ifanc's core aim is the establishment of an independent Welsh Republic with a seat in the General Assembly of the United Nations and a full member of a socially just and politically united European Union. As well as being an organization committed to the self-determination of all peoples, it is committed to achieving social justice, defending human rights and the safeguarding of the environment. ${ }^{31}$

These were the words of one member as he outlined plans for Plaid Ifanc's annual campaign to delegates at their first National Council meeting: "When we look back at what began changing minds about independence, let us be able to say it was this". ${ }^{32}$

Another development being put forward, this time by Plaid AM Adam Price is a specific development area for the West of Wales called Arfor. Essentially conceived as an area in which the Welsh language could find sanctuary, its boundaries encompass the counties of 
north and west Wales with high percentages of Welsh speakers. When the two maps are laid side by side, the resemblances become very clear ${ }^{33}$ :
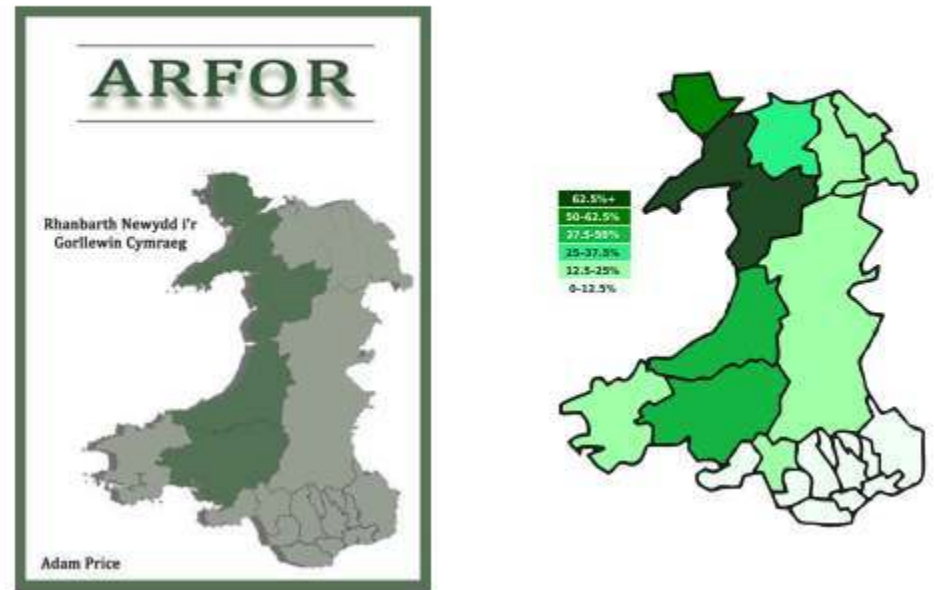

Critics have been quick to refer to it as a kind of Welsh Gaeltacht. Its proponents point out the common factors among the four counties that could make up Arfor, giving purpose to such a regional authority, among which are highlighted the high percentage of Welsh speakers, an inflow of older people coupled with an outflow of young people, rural dependence on agriculture, food and tourism, a preponderance of market towns and university towns, a high percentage of public sector jobs and some of the lowest wages in Britain, and among the lowest wages in Europe.

Arfor's remit over time could include: proposing a growth deal for the West of Wales to the UK Government; creating a strategic development plan for the Welsh West; creating a community bank for the region; creating a comprehensive language scheme across the region and across the public sector within the region; using a model of a combined authority and elected Mayors as possibilities for debates on governance.

The more astute observers will have spotted that the region put forward for Arfor just so happens to be controlled by Plaid local councils and represented in Westminster by Plaid MPs. Unfortunately, there is probably little appetite, even within core Plaid supporters, in particular in South Wales, for a scheme that seems to suggest that the party is retreating into a linguistic hinterland, one that alienates almost $90 \%$ of the population of Wales.

Moreover, given the way the Brexit negotiations have progressed - or not progressed between the UK government and the devolved nations, the very idea of devolution could be under threat after Brexit. Strategically, this is not the time for Plaid to be splitting its electorate along age-old linguistic lines that have never proved fertile in the past.

\section{Conclusion}

This paper set out to determine whether the 2017 General Election in Ceredigion in which Ben Lake gained the seat from the LibDem incumbent could in some way be seen as the beginning of a change in direction for Plaid Cymru. As the fallout from the EU Referendum settles and Brexit draws inexorably closer, Plaid Cymru finds itself at a crossroads. It is patently clear that the party was not able to cash in on its move to the 
left under Leanne Wood in the 2017 General Election; if this had been the case the party would have successfully wooed voters in the South Wales Valleys and posed a greater threat to Welsh Labour, neither of which it succeeded in doing.

It is also demonstrably clear that Plaid Cymru is now under pressure from various campaign groups within and without the party. More recently Wood's very leadership has been questioned and she has had to take robust action to defend herself ${ }^{34}$. Younger Welsh voters are increasingly turning to non-political groups like YesCymru for political inspiration, which could force Plaid to espouse the push for independence and, in so doing, possibly alienate its core British-identifying voters among Welsh-speakers and non-Welsh-speakers alike.

To some observers the situation might look worryingly similar to the political landscape of the 1970s, a time when Plaid in Wales tried desperately to reconcile its rural Western base whilst making forays into the industrial heartlands of the south. Even then, Europe as the great healer or divider, depending on which side of the socialist line one stood, was always present. Back in the 1970s Plaid found itself navigating between the dangers of a "Fortress Gwynedd" 35 and a watered-down socialism in which the Welsh language would have been all but absent. The party may find itself being drawn by opposing forces once again and, provided that bridges are dutifully built between the different communities of Wales, they may also realize that the words of The Mabinogion - A fo ben bid bont constitute the only way forward.

Carys Lewis is a senior lecturer in English in the Modern Languages Department of the University of Caen. She earned her doctorate from the University of Brest for research on Raymond Williams and has published widely on Williams, the representation of social class in the UK and on Wales. Her research interests include devolution, cultural studies in the UK and politics and culture in Wales. She is a native Welsh-speaker, having been educated from nursery school to degree level through the medium of Welsh.

\section{BIBLIOGRAPHY}

Aberystwyth, https://www.aberystwyth.org.uk/more/statistics.shtml Consulted August 11, 2017 Anon, The Guardian, April 11, 2017. https://www.theguardian.com/politics/2017/apr/11/theresamay-on-easter-break-in-snowdonia-as-row-over-syria-heats-up Consulted September 15, 2017

BBC, http://www.bbc.com/news/uk-wales-mid-wales-40276669 Consulted September 12, 2017 British Election Study, http://www.britishelectionstudy.com/bes-impact/the-brexit-electionthe-2017-general-election-in-ten-charts/\#.WsOcDJouDIV Consulted August 11, 2017.

http://www.britishelectionstudy.com/bes-impact/the-myth-of-the-2017-youthquake-election/ \#.WsXWrpouDIU Consulted March 4, 2018. 
The Cambrian News, http://www.cambrian-news.co.uk/article.cfm?id=119216\&headline=28\% 20per\%20cent\%20of\%20children\%20in\%20Ceredigion\%20living\%20in\% 20poverty\&sectionIs=news\&searchyear=2018 Consulted February 20, 2018.

Carl, Noah, CSI Brexit 3: National Identity and Support for Leave versus Remain, (Centre for Social Investigation, Nuffield College, 29th November, 2017).

Carmarthenshire's Voice, https://www.carmarthenshiresvoice.org.uk/region_for_west_wales Consulted August 11, 2017.

Cadwalladr, Carole, The Guardian, June 25, 2016. https://www.theguardian.com/uk-news/2016/ jun/25/view-wales-town-showered-eu-cash-votes-leave-ebbw-vale\#img-1 Consulted June 25, 2016.

Clarke, Stephen, Get a Move On? The Decline in Regional Job-to-Job Moves and its Impact on Productivity and Pay, (Resolution Foundation, August 2017).

Dolan, Rachel, Key Statistics for Ceredigion, (National Assembly for Wales, 2010).

Eurostat, http://ec.europa.eu/eurostat/statistics-explained/index.php/

File:Gross_domestic_product_(GDP)_per_inhabitant_in_purchasing_power_standards_ (PPS)_in_relation_to_the_EU-28_average,_by_NUTS_2_regions,_2015_(\% 25_of_the_EU-28_average,_EU-28_\%3D_100)_MAP_RYB17.png. Consulted August 11, 2017.

Evans, Daniel John, 'Welshness in 'British Wales: Negotiating National Identity at the Margins', in Nations and Nationalism, (Journal of the Association for the Study of Ethnicity and Nationalism, 2018, 1-24).

Morgan, Gerald, Ceredigion, A Wealth of History, (Gomer Press, Llandysul, Ceredigion, 2005).

Office for National Statistics (ONS), https://www.ons.gov.uk/employmentandlabourmarket/ peopleinwork/earningsandworkinghours/bulletins/ annualsurveyofhoursandearnings/2017provisionaland2016revisedresults\#regional-earnings Consulted August 11, 2017.

Parker, Mike, See http://www.mikeparker.org.uk/greasypoll.html Consulted November 4, 2017. Petition Parliament UK, https://petition.parliament.uk/archived/petitions/171928 Consulted November 6, 2017.

Plaid Ifanc, http://www.plaidifanc.org/en/who-are-we/ Consulted on September 12, 2017.

StatsWales, https://statswales.gov.wales/Catalogue/Welsh-Language/WelshSpeakers-byLocalAuthority-Gender-DetailedAgeGroups-2011Census Consulted August 11, 2017.

https://statswales.gov.wales/Catalogue/Business-Economy-and-Labour-Market/People-andWork/Earnings/averageweeklyearnings-by-welshlocalareas-year Consulted August 11, 2017.

https://statswales.gov.wales/Catalogue/Equality-and-Diversity/National-Identity/ nationalidentity-by-area-identity. Consulted March 13, 2018.

Walesonline, www.walesonline.co.uk/news/politics/full-eu-referendum-results-map-11510374 Consulted June 24, 2016.

https://www.walesonline.co.uk/news/politics/who-ben-lake-plaid-cymrus-13161075 Consulted June 9, 2017.

https://www.walesonline.co.uk/news/politics/full-eu-referendum-results-map-11510374 Consulted June 24, 2016. 
https://www.walesonline.co.uk/news/politics/full-general-election-results-wales-13159082.

Consuted June 9, 2017.

Williams, Raymond, The Fight for Manod, (Chatto and Windus, London, 1979).

YesCymru, https://yes.cymru/. Consulted August 11, 2017

\section{NOTES}

1. The Guardian, April 11, 2017. https://www.theguardian.com/politics/2017/apr/11/theresamay-on-easter-break-in-snowdonia-as-row-over-syria-heats-up Consulted September 15, 2017.

2. Welsh speakers by local authority, gender and detailed age groups, 2011 Census. https:// statswales.gov.wales/Catalogue/Welsh-Language/WelshSpeakers-by-LocalAuthority-GenderDetailedAgeGroups-2011Census Consulted August 11, 2017.

3. A 2010 survey conducted by the National Assembly for Wales showed that $37.7 \%$ of the population of Ceredigion was born outside Wales in other parts of the UK (compared to $21.4 \%$ for the whole of Wales). The same study gives the figure of $1.7 \%$ who were born elsewhere in the EU (against $1.3 \%$ for the whole of Wales). Dolan, Rachel, Key Statistics for Ceredigion, National Assembly for Wales, 2010, p. 11.

4. https://www.aberystwyth.org.uk/more/statistics.shtml Consulted August 11, 2017.

5. Ceredigion voted 54.6 per cent to 45.4 per cent to remain in the EU, one of only five council areas to do so in Wales. www.walesonline.co.uk/news/politics/full-eu-referendum-resultsmap-11510374 Consulted June 24, 2016.

6. It was claimed that in a YouGov poll of 80,000 Britons, Ceredigion was found to be the most enthusiastically pro-EU of all 188 areas surveyed https://www.independent.co.uk/news/uk/ home-news/aberystwyth-welcome-to-the-most-europhile-place-in-britain-a6913001.html.

Consulted November 4, 2017. In the same article Ceredigion is described as "Wales's California". The county was also illustriously crowned the most intensely opposed to a state visit by US President Donald Trump in a petition submitted to the 2015-2017 Conservative government https://petition.parliament.uk/archived/petitions/171928 Consulted November 6, 2017.

7. Rachel Dolan, Key Statistics for Ceredigion, p. 5.

8. https://statswales.gov.wales/Catalogue/Business-Economy-and-Labour-Market/People-andWork/Earnings/averageweeklyearnings-by-welshlocalareas-year Consulted August 11, 2017

9. https://www.ons.gov.uk/employmentandlabourmarket/peopleinwork/ earningsandworkinghours/bulletins/

annualsurveyofhoursandearnings/2017provisionaland2016revisedresults\#regional-earnings Consulted August 11, 2017

10. http://www.cambrian-news.co.uk/article.cfm?id=119216\&headline $=28 \% 20$ per $\% 20$ cent $\% 20$ of \%20children\%20in\%20Ceredigion\%20living\%20in\%20poverty\&sectionIs=news\&searchyear=2018 Consulted February 20, 2018

11. http://ec.europa.eu/eurostat/statistics-explained/index.php/File:Gross_domestic_product_ (GDP)_per_inhabitant_in_purchasing_power_standards_

(PPS)_in_relation_to_the_EU-28_average,_by_NUTS_2_regions,_2015_(\%

25_of_the_EU-28_average,_EU-28_\%3D_100)_MAP_RYB17.png Consulted August 11, 2017

12. Gerald Morgan, Ceredigion, A Wealth of History, Gomer Press, Llandysul, Ceredigion, 2005, pp. 285-286.

13. Ibid., p. 290.

14. Ibid., p. 211.

15. Ibid., p. 293. The words were used in Davies's official campaign for the Cardiganshire seat in 1885.

Revue Française de Civilisation Britannique, XXIII-2 | 2018 
16. Ibid., p. 294.

17. Mike Parker, the Plaid candidate, was accused of calling English incomers to rural Wales Nazis. This was splashed across the front page of the local newspaper in what amounted to the tendentious and sensationalist reporting of a past article Parker had written on BNP leader Nick Griffin's settling in Wales to escape multicultural Britain. Parker has since written a book about his experience. See http://www.mikeparker.org.uk/greasypoll.html Consulted November 4, 2017 18. The earliest prose stories of the literature of Britain, they were compiled in Welsh during the $12^{\text {th }}$ or $13^{\text {th }}$ centuries, but drew on much older sources from the oral tradition. The first manuscripts in which they are found date back to the $14^{\text {th }}$ and $15^{\text {th }}$ centuries. In the second branch, Branwen ferch Llyr (Branwen daughter of Llyr), the heroine's brother, the giant Bendigeidfran or Brân, sets off with his Welsh army to rescue his sister who is being mistreated and has been imprisoned by her Irish husband. Once the Welsh army set foot on Irish soil, they are faced with the difficulty of crossing the river Liffey. As there is no bridge, Brân decides to lie down across the river, thus enabling the massed armies of the Welsh to ride over his body. It is at this point in the story that he utters the words that have become a Welsh proverb: $A$ fo ben bid bont. The proverb is the motto of Penweddig Welsh-Medium Comprehensive School in Aberystwyth.

19. Walesonline, June 9, 2017. https://www.walesonline.co.uk/news/politics/who-ben-lakeplaid-cymrus-13161075 Consulted June 9, 2017.

20. Noah Carl, CSI Brexit 3: National Identity and Support for Leave versus Remain, Centre for Social Investigation, Nuffield College, 29th November, 2017, p. 4.

21. For an interesting recent discussion on self-identity and the language question in Wales, see Evans, Daniel John, 'Welshness in 'British Wales: Negotiating National Identity at the Margins', Nations and Nationalism, 2018, 1-24.

22. Source: @dafyddelfryn, March 5, 2018. Elfryn is a young graphic designer from the Caernarfon area. He takes statistics about Wales and turns them into maps. The statistics in the map here come from the Welsh Government StatsWales website : https://statswales.gov.wales/ Catalogue/Equality-and-Diversity/National-Identity/nationalidentity-by-area-identity.

Consulted March 13, 2018.

23. Source: walesonline.com, 24 June, 2016 https://www.walesonline.co.uk/news/politics/fulleu-referendum-results-map-11510374 and 9 June, 2017 https://www.walesonline.co.uk/news/ politics/full-general-election-results-wales-13159082. Site consulted on June 24, 2016 and June 9, 2017.

24. http://www.britishelectionstudy.com/bes-impact/the-brexit-election-the-2017-generalelection-in-ten-charts/\#.WsOcDJouDIV Consulted August 11, 2017.

25. 'Bodlondeb Aberystwyth home closure would leave 'huge hole", June 16, 2017. http:// www.bbc.com/news/uk-wales-mid-wales-40276669 Consulted September 12, 2017.

26. Carole Cadwalladr, "View from Wales: town showered with EU cash votes to leave EU", The Guardian, June 25, 2016. https://www.theguardian.com/uk-news/2016/jun/25/view-wales-townshowered-eu-cash-votes-leave-ebbw-vale\#img-1 Consulted June 25, 2016.

27. http://www.britishelectionstudy.com/bes-impact/the-myth-of-the-2017-youthquakeelection/\#.WsXWrpouDIU Consulted March 4, 2018.

28. Ben Lake's maiden speech in Westminster, July 13, 2017. http://www2.partyof.wales/ benlakespeech. Consulted September 12, 2017.

29. Stephen Clarke, Get a Move On? The Decline in Regional Job-to-Job Moves and its Impact on Productivity and Pay, Resolution Foundation, August 2017, see in particular maps on p. 13.

30. https://yes.cymru/. Consulted August 11, 2017.

31. Our Constitution on http://www.plaidifanc.org/en/who-are-we/ Consulted on September 12, 2017.

32. Ibid. 
33. Plaid Cymru, August 10, 2017 https://www.carmarthenshiresvoice.org.uk/ region_for_west_wales Consulted August 11, 2017. Map of Wales showing percentages of Welshspeakers in 2011 Census.

34. https://www.walesonline.co.uk/news/politics/neil-mcevoy-suspended-plaidcymru-14431383 Consulted March 20, 2018.

35. Cf Raymond Williams, The Fight for Manod, Chatto and Windus, 1979. In this novel Raymond Williams explored in fiction the intricacies of rural development in mid Wales through the fictional fight to save an agricultural community. The threats came from within and without. Matthew Price, a young Oxford researcher who has been asked to work on the development plan, is hostile to the idea of going back to "traditional rural Wales" and is mocked by Tom Meurig, a Welshman living locally but who had returned to Wales after studies in Oxford and Europe. Meurig's response to Price is to chide him for imagining that tradition, or in Meurig's words, "Fortress Gwynedd", is all rural Wales has to offer. The Fight for Manod, The Hogarth Press, 1985, p. 136.

\section{ABSTRACTS}

The narrow win after two recounts of Plaid Cymru's Ben Lake in the Ceredigion constituency at the June $8^{\text {th }}$ General Election could be seen as heralding a new dawn in the fortunes of the Party of Wales. Ceredigion itself stood out in the UK as the most pro-EU region in the country in a poll taken before the EU referendum, a trait that was borne out by the county's $54.63 \%$ vote for Remain. This is therefore a part of the world that is something of a paradox: this extremely rural constituency - some of the least densely-populated parts of the UK are to be found within its boundaries - melds together a variety of co-existing communities: old and new, touristorientated coast and agricultural hinterland, low-wage labourers and high-earning university staff. It is home to some of the strongest Welsh-speaking areas in Wales whilst witnessing an exodus of its young people and in-migration from beyond its borders.

The present paper will seek to examine what the Ceredigion result may indicate by focusing on the question of the youth vote and the possible spearheading of a change in Plaid tactics regarding the question of independence for Wales, a position that has rarely found any support among core Plaid voters in rural Welsh-speaking Wales. We will also seek to zoom in on the 'Arfor' plan, a Plaid-backed vision of new regional governance for the West of Wales, in which language planning and economic development go hand in hand. Could this new polity stave off the worst effects of Brexit in Ceredigion and enable the county to put an end to "this steady, silent haemorrhage" that "saps the life of nearly every town and village the length and breadth of the county", as reflected in the words of Ben Lake's maiden speech in Westminster?

Il aura fallu recompter les bulletins à deux fois pour enfin départager les candidats et déclarer la victoire de Ben Lake, candidat de Plaid Cymru, dans la circonscription du Ceredigion lors de l'élection législative britannique de 2017. L'article cherche à déterminer si la victoire de Lake constitue un nouveau départ pour le Parti du pays de Galles ("The Party of Wales») dans une circonscription qui a voté pour le maintien du Royaume-Uni dans l'Union européenne à 54.63\%. Comté rural avant tout, le Ceredigion recèle néanmoins quelques paradoxes : une population jeune d'étudiants cohabite côte à côte avec bon nombre de retraités venus chercher le repos et le silence dans une des régions les moins peuplées du royaume. Un tourisme familial contribue 
autant à l'économie locale que les paysans taiseux de l'arrière-pays. L'emploi reflète les polarités entre ouvriers non-qualifiés du secteur marchand et les enseignants-chercheurs des deux universités implantées dans le comté. Le Ceredigion est également une région où la langue galloise tient encore le haut du pavé, alors que ses jeunes s'exilent inexorablement, faute d'emplois, remplacés par des gens pour qui la langue n'a pas autant d'attraits.

Nous chercherons à examiner l'importance du résultat dans le Ceredigion en nous focalisant sur le vote des jeunes et en quoi ceci pourrait conduire Plaid Cymru à changer sa politique envers une éventuelle indépendance galloise, politique qui n'a pas attiré jusqu'ici l'adhésion de ses électeurs traditionnels issus des communautés rurales galloises. Nous nous pencherons aussi sur le projet ' Arfor', une vision nouvelle pour l'ouest du pays de Galles où développement économique et sauvegarde de la langue galloise avancent main dans la main. Une question donc se pose : le projet Arfor réussira-t-il à protéger le Ceredigion des pires effets du Brexit et permettra-t-il à ce comté rural de "mettre un terme à l'hémorragie lente et silencieuse qui vide de son sang chaque ville et chaque village d'un bout à l'autre de son territoire", souhait exprimé de tous ses vœux par Ben Lake, le jeune député fraîchement élu, dans son premier discours devant ses pairs à Westminster?

\section{INDEX}

Mots-clés: pays de Galles, Plaid Cymru, comté du Ceredigion, indépendance, Brexit

Keywords: Wales, Plaid Cymru, Ceredigion, Welsh independence, Brexit

\section{AUTHOR}

\section{CARYS LEWIS}

Université de Caen 